\title{
FAKTOR RISIKO STUNTING PADA ANAK BALITA DI KABUPATEN LAMPUNG TENGAH
}

Milantika Kristanti ${ }^{1 *}$, Nayla Kamilia Fithri ${ }^{2}$

\section{1,2 Fakultas Kesehatan Masyarakat Universitas Esa Unggul, Jakarta, Indonesia}

\section{Artikel Info :}

Received 14 April 2021

Accepted 21 April 2021

Available online 31 Agustus

2021

Editor: Prayudhy Yushananta

Keyword :

Children, poverty, stunting,

sanitation, case-control

Kata kunci :

Balita, kemiskinan, stunting, sanitasi, kasus-kontrol

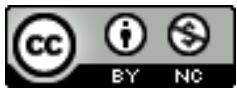

Ruwa Jurai: Jurnal

Kesehatan Lingkungan is licensed under a Creative Commons

Attribution-NonCommercial 4.0

International License.

\begin{abstract}
A bstract
Stunting is stunted growth in children due to malnutrition. It can affect children's cognitive and physical development, increase the risk of infection, and significantly contribute to child morbidity and mortality. This study aims to analyze the risk factors for stunting in children under five (13-59 months). The study used a case-control design to compare previous exposure to stunting and normal children under five. Measurements and interviews were conducted with 120 children under five and their mothers. The SPSS (24.0) was used for the Chi-square and Odds Ratio (alpha $=5 \%$ ) test. The study found the risk factors for stunting under five, poor income (OR $=4.75 ; 95 \% \mathrm{Cl} 2.18-10.33)$, not getting exclusive breastfeeding $(O R=5.29 ; 95 \% \mathrm{Cl} 2.39-11.68)$ ), there is no access to clean water $(O R=3.00 ; 95 \% \mathrm{Cl} 1.42-6.32)$, and healthy latrines $(O R=3.73$; 95\% Cl 1.75-7.94). Increasing the nutritional status of pre-pregnant and pregnant women and access to clean water and healthy latrines to prevent infection is an urgent need to be implemented immediately.
\end{abstract}

Stunting adalah terhambatnya pertumbuhan pada anak-anak akibat malnutrisi, dan dapat mempengaruhi perkembangan kognitif dan fisik anak-anak, meningkatkan risiko infeksi dan secara signifikan berkontribusi terhadap morbiditas dan mortalitas anak. Penelitian bertujuan menganalisis faktor risiko kejadian stunting pada anak balita (13-59 bulan). Penelitian menggunakan rancangan case control untuk membandingkan paparan sebelumnya pada anak balita stunting dan normal. Pengukuran dan wawancara dilakukan terhadap 120 anak balita dan ibunya. Perangkat SPSS (24.0) digunakan untuk uji Chi-square dan Odds Ratio (alpha=5\%). Penelitian mendapatkan faktor risiko balita stunting, penghasilan kurang baik $(O R=4,75 ; 95 \% \mathrm{Cl}$ 2,18-10,33), tidak mendapatkan ASI eksklusif (OR=5,29; 95\%CI 2,39-11,68), tidak terakses air bersih (OR=3,00; 95\% Cl 1,42-6,32), dan jamban sehat (OR=3,73; $95 \% \mathrm{Cl}$ 1,75-7,94). Meningkatkan status gizi ibu pra-hamil dan hamil, serta akses terhadap air bersih dan jamban sehat untuk mencegah infeksi menjadi kebutuhan mendesak untuk segera dilaksanakan.

Corresponding author: Milantika Kristanti

Fakultas Kesehatan Masyarakat Universitas Esa Unggul, Jakarta Barat, Indonesia

Email: milantikakristanti@yahoo.com

\section{PENDAHULUAN}

Gizi buruk (malnutrisi) menyebabkan terhambatnya pertumbuhan pada anak-anak, sehingga tinggi badan tidak sesuai dengan umurnya. Kondisi ini disebut dengan balita pendek atau stunting (Ministry of Health Indonesia, 2010; UNICEF Indonesia, 2018; WHO, 2017). Secara umum, terdapat tiga indikator status gizi anak yang dikenal luas, yaitu stunting, wasting dan underweight (Barth-Jaeggi et al.,
2020; Bomela, 2009; Kang et al., 2018; Karpati et al., 2020; Khan et al., 2019; WHO, 2017). Namun stunting mengindikasikan bentuk malnutrisi kronis (Barth-Jaeggi et al., 2020; Kang et al., 2018; Karpati, Neubourg, Laillou, \& Poirot, 2020; Khan, Zaheer, \& Safdar, 2019; WHO, 2017). Stunting pada masa kanak-kanak adalah ukuran terbaik dari malnutrisi dan biaya jangka panjangnya bagi masyarakat (Victora et al., 2008). 
Pada tahun 2012, sebanyak 162 juta balita di dunia mengalami stunting, 56\% di Asia dan 36\% di Afrika. Di Indonesia, berdasarkan hasil Riset Kesehatan Dasar (Riskesdas) tahun 2013, prevalensi stunting mencapai 37,2\%, meningkat dari tahun 2010 (35,6\%) dan 2007 (36,8\%). Indonesia menempati peringkat kelima terbanyak di dunia, dan lebih tinggi dibandingkan negara-negara lain di Asia Tenggara (MCA-Indonesia, 2013).

Hasil Riskesdas tahun 2018, terjadi penurunan prevalensi stunting menjadi $30,8 \%$, terdiri dari sangat pendek $11,5 \%$ dan pendek 19,3\% (Ministry of Health Indonesia, 2018, 2010; WHO, 2017). Menurut WHO, stunting menjadi masalah kesehatan masyarakat jika prevalensinya lebih dari 20\%, sehingga harus ditanggulangi (Kemenkes RI, 2016). Tingginya indikator gizi buruk di suatu negara mencerminkan buruknya status gizi dan kesehatan balita di negara tersebut, sehingga perlu dicari faktor-faktor yang terkait dengan gizi buruk pada anak-anak (Ministry of Health Indonesia, 2018, 2010; WHO, 2017).

Stunting akan mempengaruhi perkembangan kognitif dan fisik anak-anak, meningkatkan risiko infeksi dan secara signifikan berkontribusi terhadap morbiditas dan mortalitas anak (Adedeji et al., 2017; Anwar et al., 2020; He et al., 2018; Hidayah et al., 2019; Imelda et al., 2020; Indah Nurdin et al., 2019; Niga and Purnomo, 2016; Nugroho, 2016; Pelletier and Frongillo, 2003; Rahman, 2018a; Widyaningsih et al., 2018). Perkembangan otak anak di masa golden period (0-3 tahun) akan terganggu, akibat terhambatnya pertumbuhan sel otak. Dampaknya, terjadi penurunan skor tes IQ sebesar 10-13 point (Par'i et al., 2017).

Stunting merupakan indikator yang sensitif untuk sosial ekonomi yang buruk, sekaligus sebagai prediktor untuk morbiditas dan mortalitas jangka panjang. Stunting pada anak usia dini bersifat reversible (Barth-Jaeggi et al., 2020). Penanggulangan stunting dimulai sejak dalam kandungan sampai anak usia 2 tahun (1000 hari pertama kehidupan), dikenal dengan periode emas (Georgiadis and Penny, 2017; Hoddinott et al., 2013; Islam et al., 2020; Kinshella et al., 2020; Ministry of Health Indonesia, 2018; National Development Planning
Agency, 2011; Victora et al., 2008; WHO, 2020, 2014).

Banyak faktor yang berkontribusi terhadap kejadian stunting. Penentu umum yang dilaporkan pada penelitian sebelumnya adalah kemiskinan, pemberian makan yang kurang optimal, kerawanan pangan rumah tangga, pendidikan dan penyakit infeksi (Adedeji et al., 2017; Anwar et al., 2020; He et al., 2018; Hidayah et al., 2019; Imelda et al., 2020; Indah Nurdin et al., 2019; Niga and Purnomo, 2016; Nugroho, 2016; Pelletier and Frongillo, 2003; Rahman, 2018a; Widyaningsih et al., 2018). Defisiensi makanan terutama protein, zat besi, zink, kalsium, dan vitamin D, A dan C (Ministry of Health Indonesia, 2018; Siringoringo et al., 2020). Penyakit infeksi akibat paparan mikroorganisme dan parasit, berkaitan erat dengan akses terhadap air bersih dan jamban sehat (BarthJaeggi et al., 2020; Bomela, 2009; Cahyono et al., 2016; Checkley, 2003; Hidayah et al., 2019; Kang et al., 2018; Karpati et al., 2020; MCA-Indonesia, 2013; Nadiyah et al., 2014; Rahman, 2018b; Yudianti and Saeni, 2017). Jalur fecal-oral adalah kontak langsung, air, makanan, alat makan, dan vektor; dikenal dengan 5F: fluids-fingers-foodfields-flies (Pickering et al., 2018). Peningkatan akses air bersih dan jamban sehat merupakan salah satu upaya menurunkan angka penyakit infeksi yang menyebabkan kematian dan gangguan pertumbuhan, terutama diare (BAPENAS, 2019).

Di Provinsi Lampung, prevalensi tertinggi kejadian stunting terdapat di Kabupaten Lampung Tengah, sebesar 37,0\% (Dinas Kesehatan Provinsi Lampung, 2019). Berdasarkan puskesmas, kejadian stunting tertinggi di wilayah kerja Puskesmas Bandar Agung, Kabupaten Lampung Tengah, yaitu di Desa Gunung Batin Udik dengan prevalensi sebesar $27,39 \%$ atau 140 dari 511 balita yang di ukur (UPT Puskesmas Bandar Agung, 2017). Penelitian bertujuan menganalisis faktor risiko kejadian stunting pada anak balita (13-59 bulan). Faktor risiko yang diteliti adalah pendapatan keluarga, ASI eksklusif, sarana air bersih, dan jamban sehat.

\section{METODE}

Penelitian menggunakan rancangan casecontrol di Desa Gunung Batin Udik, Kabupaten 
Lampung Tengah, untuk membandingkan paparan sebelumnya pada anak balita stunting (kasus) dan non-stunting (kontrol). Populasi adalah seluruh anak balita umur 13-59 bulan yang berdomisili di lokasi penelitian sekurangkurangnya pada enam bulan terakhir, tidak menderita cacat atau kelainan.

Kasus adalah anak dengan stunting (skor $\mathrm{z}$ tinggi untuk usia <-2 skor z). Kontrol adalah anak-anak yang tidak stunting (skor $\mathrm{z}$ tinggi untuk usia $\geq-2$ skor $z$ ), dipilih dari tetangga terdekat kasus yang sebaya. Jika beberapa kontrol ditemukan, mereka dipilih secara acak. Menggunakan perbandingan sama (1:1), jumlah sampel penelitian sebanyak 120 balita, terdiri dari 60 kasus dan 60 kontrol.

Data dikumpulkan dengan pengukuran, wawancara dan observasi. Seluruh balita diukur tinggi/panjang badannya menggunakan standard WHO. Balita umur <24 bulan dengan posisi tidur, dan balita umur 24-59 bulan diukur dengan posisi berdiri. Seluruh data dianalisis dengan perangkat SPSS 24.0. Teknik analisis (alpha $=5 \%$ ) yang digunakan adalah frekuensi, proporsi, Chi-square, Odds Ratio.

\section{HASIL}

Hasil penelitian (Tabel 1) mendapatkan balita lebih banyak berada pada keluarga dengan penghasilan yang kurang baik (73,3\%). Proporsi dominan juga terdapat pada balita yang tidak mendapatkan ASI eksklusif (76,7\%). Faktor lingkungan berkaitan erat dengan penyakit infeksi terutama diare. Penelitian menemukan $60,0 \%$ balita stunting tinggal di rumah yang tidak terakses air bersih dan $68,3 \%$ tidak terakses jamban sehat.

Tabel 1. Distribusi responden berdasarkan variabel penelitian

\begin{tabular}{lllcc}
\hline Variabel Penelitian & \multicolumn{3}{c}{ Kasus $=60$} & \multicolumn{3}{c}{ Kontrol $=60$} \\
\cline { 2 - 5 } & $\mathrm{n}$ & $\%$ & $\mathrm{n}$ & $\%$ \\
\hline $\begin{array}{l}\text { Pendapatan Keluarga } \\
\quad \text { Kurang baik }\end{array}$ & 44 & 73,3 & 22 & 36,7 \\
$\quad$ Baik & 16 & 26,7 & 38 & 63,3 \\
$\begin{array}{l}\text { Riwayat Pemberian ASI } \\
\quad \text { Tidak Eksklusif }\end{array}$ & 46 & 76,7 & 23 & 38,3 \\
$\quad$ Eksklusif & 14 & 23,3 & 37 & 61,7 \\
$\begin{array}{l}\text { Air Bersih } \\
\quad \text { Tidak terakses }\end{array}$ & 36 & 60,0 & 20 & 33,3 \\
$\quad$ Terakses & 24 & 40,0 & 40 & 66,7 \\
Jamban Sehat & & & & \\
$\quad$ Tidak terakses & 41 & 68,3 & 22 & 36,7 \\
$\quad$ Terakses & 19 & 31,7 & 38 & 63,3 \\
\hline
\end{tabular}

Uji Chi-square dan Odds Ratio diterapkan untuk mengetahui hubungan masing-masing faktor independen dengan stunting. Tabel 2 menunjukkan bahwa balita dari keluarga dengan pendapatan kurang baik, berisiko 4,75 kali $(2,18-$ $10,33)$ menjadi stunting $(p<0,01)$. Pemberian ASI eksklusif berhubungan erat dengan kejadian stunting $(p<0,01)$, dan memberikan nilai risiko sebesar 5,29 kali $(2,39-11,68)$.

Akses terhadap air bersih menunjukkan hubungan yang signifikan dengan kejadian stunting $(p<0,01)$, dan meningkatkan risiko sebesar 3,00 kali $(1,42-6,32)$. Sedangkan akses jamban sehat, meningkatkan risiko sebesar 3,73 kali $(1,75-7,94)$ terhadap kejadian stunting.

\section{PEMBAHASAN}

Penelitian mendapatkan hubungan yang signifikan antara pendapatan keluarga dengan stunting. Risiko balita dari keluarga berpenghasilan mengalami stunting, 4,75 kali $(2,18-10,33)$ kali lebih besar dibandingkan yang penghasilan baik (Tabel 2). Pendapatan keluarga merupakan faktor yang paling menentukan terhadap kuantitas dan kualitas konsumsi makanan. Rendahnya pendapatan (kemiskinan) menyebabkan daya beli terhadap makanan menjadi rendah, sehingga konsumsi gizi menjadi berkurang, baik kebutuhan gizi ibu selama kehamilan dan gizi balita. Kemiskinan merupakan penentu umum dari malnutrisi yang 
menyebabkan kerawanan pangan rumah tangga dan tidak optimalnya pemberian makanan pada balita (Adedeji et al., 2017; Anwar et al., 2020; He et al., 2018; Hidayah et al., 2019; Imelda et al., 2020; Indah Nurdin et al., 2019; Niga and Purnomo, 2016; Nugroho, 2016; Pelletier and Frongillo, 2003; Rahman, 2018a; Widyaningsih et al., 2018).

Kerawanan makanan dalam keluarga berakibat pada menurunnya ragam dan nilai gizi makanan yang dikonsumsi. Penurunan ini mengakibatkan semakin beratnya masalah gizi masyarakat, termasuk pada wanita hamil yang berdampak pada kelahiran bayi stunting (Ministry of Health Indonesia, 2018; Siringoringo et al., 2020). Keterbatasan akses dan ketersediaan pangan merupakan gabungan dari masalah kemiskinan, kurangnya pekerjaan tetap (National Development Planning Agency, 2011). Rendahnya daya beli berpengaruh terhadap status gizi keluarga, termasuk tumbuh kembang anak (Kusumawati et al., 2015). Kurangnya jumlah dan kualitas pangan disebabkan ketidakcukupan uang untuk membeli bahan makanan (Galler et al., 2012; Kusumawati et al., 2015).

Tabel 2. Distribusi sarana sanitasi berdasarkan kejadian Stunting

\begin{tabular}{|c|c|c|c|c|c|c|}
\hline \multirow{2}{*}{ Variabel Penelitian } & \multicolumn{2}{|c|}{ Kasus $=60$} & \multicolumn{2}{|c|}{ Kontrol $=60$} & \multirow{2}{*}{$P$-value } & \multirow{2}{*}{ OR (Cl 95\%) } \\
\hline & $\mathrm{n}$ & $\%$ & $\mathrm{n}$ & $\%$ & & \\
\hline \multicolumn{7}{|c|}{ Pendapatan Keluarga } \\
\hline Kurang baik & 44 & 73,3 & 22 & 36,7 & \multirow{2}{*}{0,0001} & 4,75 \\
\hline Baik & 16 & 26,7 & 38 & 63,3 & & $(2,18-10,33)$ \\
\hline \multicolumn{7}{|c|}{ Riwayat Pemberian ASI } \\
\hline Tidak Eksklusif & 46 & 76,7 & 23 & 38,3 & \multirow[t]{2}{*}{0,0001} & 5,29 \\
\hline Eksklusif & 14 & 23,3 & 37 & 61,7 & & $(2,39-11,68)$ \\
\hline \multicolumn{7}{|l|}{ Air Bersih } \\
\hline Tidak terakses & 36 & 60,0 & 20 & 33,3 & \multirow[t]{2}{*}{0,006} & 3,00 \\
\hline Terakses & 24 & 40,0 & 40 & 66,7 & & $(1,42-6,32)$ \\
\hline \multicolumn{7}{|l|}{ Jamban Sehat } \\
\hline Tidak terakses & 41 & 68,3 & 22 & 36,7 & \multirow[t]{2}{*}{0,001} & \multirow{2}{*}{$\begin{array}{l}3,73 \\
(1,75-7,94)\end{array}$} \\
\hline Terakses & 19 & 31,7 & 38 & 63,3 & & \\
\hline
\end{tabular}

Pemberian ASI tidak eksklusi meningkatkan risiko stunting 5,29 kali (Tabel 2). ASI adalah makanan terbaik bagi bayi baru lahir, baik yang dilahirkan cukup bulan maupun kurang bulan. ASI berkaitan imunitas anak terhadap penyakit infeksi, menurunkan frekuensi diare, konstipasi kronis dan lain sebagainya (Umboh et al., 2013). Kurangnya pemberian ASI dapat meningkatkan risiko terjadinya stunting terutama pada awal kehidupan (Adair and Guilkey, 1997).

Menurut WHO, terdapat empat hal penting yang harus dilakukan untuk mencapai tumbuh kembang optimal, yaitu: memberikan ASI segera dalam 30 menit setelah bayi lahir, memberikan hanya ASI saja (ASI Eksklusif) hingga bayi berusia 6 bulan, memberikan Makanan Pendamping Air Susu Ibu (MP-ASI) sejak bayi berusia 6-24 bulan, dan meneruskan pemberian ASI sampai anak berusia 24 bulan atau lebih (AL Rahmad et al., 2013; Engle et al., 1999).
Penelitian mendapatkan hubungan yang signifikan antara kejadian stunting dengan akses air bersih $(p<0,01 ; O R=3,00 ; 95 \% C l 1,42-6,32)$, dan akses jamban sehat $(p<0,01 ; O R=3,73$; $95 \% \mathrm{Cl} 1,75-7,94)$. Akses terhadap air bersih dan jamban sehat berkaitan dengan infeksi mikroorganisme dan parasit yang menjadi salah satu faktor penyebab langsung masalah gizi (Kusumawati et al., 2015). Energi yang seharusnya untuk pertumbuhan, digunakan untuk melawan infeksi. Sehingga anak mengalami kekurangan energi, dan berakibat pada gangguan pertumbuhan (MCA-Indonesia, 2013).

Hasil yang sama juga disampaikan (Checkley, 2003), gangguan pertumbuhan linier (stunting) sering terjadi pada balita miskin di Peru akibat penyakit diare yang berhubungan dengan sanitasi yang buruk. Hubungan stunting dengan infeksi terutama diare, akibat akses air bersih 
dan jamban sehat juga disampaikan oleh (BarthJaeggi et al., 2020; Cahyono et al., 2016; Hidayah et al., 2019; Kang et al., 2018; Karpati et al., 2020; Nadiyah et al., 2014; Rahman, 2018b; Yudianti and Saeni, 2017). Hasil penelitian di banyak negara menyimpulkan bahwa stunting faktor sosial ekonomi yang berdampak pada masalah gizi selama kehamilan, gizi pertumbuhan anak, dan infeksi akibat rendahnya akses air bersih dan jamban sehat (Kusumawati et al., 2015).

\section{SIMPULAN}

Penelitian mendapatkan faktor risiko balita stunting di lokasi penelitian adalah rendahnya penghasilan keluarga, praktik pemberian ASI yang kurang baik, serta rendahnya akses terhadap air bersih dan jamban sehat. Diduga, kemiskinan sebagai penyebab utama balita stunting. Meningkatkan status gizi ibu hamil, pemberian makanan tambahan (PMT-ASI), penyembuhan infeksi, serta meningkatkan akses terhadap air bersih dan jamban sehat menjadi kebutuhan mendesak untuk segera dilaksanakan.

\section{DAFTAR PUSTAKA}

Adair, L.S., Guilkey, D.K., 1997. Age-Specific Determinants of Stunting in Filipino Children. The Journal of Nutrition 127, 314-320.

Adedeji, I., John, C., Okolo, S., Ebonyi, A., Abdu, H., Bashir, M., 2017. Malnutrition and the Intelligence Quotient of Primary School Pupils in Jos, Nigeria. British Journal of Medicine and Medical Research 21, 1-13.

AL Rahmad, A.H., Miko, A., Hadi, A., 2013. Kajian Stunting Pada Anak Balita Ditinjau Dari Pemberian ASI Eksklusif, MP-ASI, Status Imunisasi Dan Karakteristik Keluarga Di Kota Banda Aceh. Jurnal Kesehatan IImiah Nasuwakes Poltekkes Aceh 6, 169-184.

Anwar, C., Abdullah, M., Sasmita, V., 2020. Stunting dan Faktor yang Berhubungan Studi Kasus Kontrol di Wilayah Kerja Puskesmas Baitussalam Kabupaten Aceh Besar 6, 988-998.

BAPENAS, 2019. Roadmap of SDGs Indonesia Towards 2030.

Barth-Jaeggi, T., Zandberg, L., Bahruddinov, M., Kiefer, S., Rahmarulloev, S., Wyss, K., 2020. Nutritional status of Tajik children and women: Transition towards a double burden of malnutrition. Maternal \& Child Nutrition 16, 111.
Bomela, N.J., 2009. Social, economic, health and environmental determinants of child nutritional status in three Central Asian Republics. Public Health Nutrition 12, 1871-1877.

Cahyono, F., Manongga, S.P., Picauly, I., 2016. Faktor Penentu Stunting Anak Balita Pada Berbagai Zona Ekosistem Di Kabupaten Kupang. Jurnal Gizi dan Pangan 11, 9-18.

Checkley, W., 2003. Effects of Acute Diarrhea on Linear Growth in Peruvian Children. American Journal of Epidemiology 157, 166-175.

Dinas Kesehatan Provinsi Lampung, 2019. Profil Kesehatan Provinsi Lampung tahun 2018. Dinas Kesehatan Provinsi Lampung, Bandar Lampung

Engle, P.L., Menon, P., Haddad, L., 1999. Care and Nutrition: Concept and Measurement, International Pood Policy Research Institute.

Galler, J.R., Bryce, C., Waber, D.P., Zichlin, M.L., Fitzmaurice, G.M., Eaglesfield, D., 2012. Socioeconomic Outcomes in Adults Malnourished in the First Year of Life: A 40-Year Study. PEDIATRICS 130, e1-e7.

Georgiadis, A., Penny, M.E., 2017. Child undernutrition: opportunities beyond the first 1000 days. The Lancet Public Health 2, e399.

He, P., Liu, L., Salas, J.M.I., Guo, C., Cheng, Y., Chen, G., Zheng, X., 2018. Prenatal malnutrition and adult cognitive impairment: a natural experiment from the 1959-1961 Chinese famine. British Journal of Nutrition 120, 198203.

Hidayah, N., Rita, W., Anita, B., Podesta, F., Ardiansyah, S., Subeqi, A.T., Nasution, S.L., Riastuti, F., 2019. Hubungan pola asuh dengan kejadian stunting (rekomendasi pengendaliannya di Kabupaten Lebong). Riset Informasi Kesehatan 8, 140.

Hoddinott, J., Alderman, H., Behrman, J.R., Haddad, L., Horton, S., 2013. The economic rationale for investing in stunting reduction. Maternal \& Child Nutrition 9, 69-82.

Imelda, I., Rahman, N., Nur, R., 2020. Faktor Risiko Kejadian Stunting Pada Anak Umur 2-5 Tahun Di Puskesmas Biromaru. Ghidza: Jurnal Gizi dan Kesehatan 2, 39-43.

Indah Nurdin, S.S., Octaviani Katili, D.N., Ahmad, Z.F., 2019. Faktor ibu, pola asuh anak, dan MPASI terhadap kejadian stunting di kabupaten Gorontalo. Jurnal Riset Kebidanan Indonesia 3, 74-81.

Islam, M.S., Zafar Ullah, A.N., Mainali, S., Imam, M.A., Hasan, M.I., 2020. Determinants of stunting during the first 1,000 days of life in Bangladesh: A review. Food Science \& Nutrition 
8, 4685-4695.

Kang, Y., Aguayo, V.M., Campbell, R.K., Dzed, L., Joshi, V., Waid, J.L., Gupta, S.D., Haselow, N.J., West, K.P., 2018. Nutritional status and risk factors for stunting in preschool children in Bhutan. Maternal \& Child Nutrition 14, 1-16.

Karpati, J., Neubourg, C., Laillou, A., Poirot, E., 2020. Improving children's nutritional status in Cambodia: Multidimensional poverty and early integrated interventions. Maternal \& Child Nutrition 16.

Kemenkes RI, 2016. Situasi Balita Pendek Di Indonesia. Kementerian Kesehatan Republik Indonesia ISSN 2442-, 1-10.

Khan, S., Zaheer, S., Safdar, N.F., 2019. Determinants of stunting, underweight and wasting among children $<5$ years of age: evidence from 2012-2013 Pakistan demographic and health survey. BMC Public Health 19, 358.

Kinshella, M.L.W., Moore, S.E., Elango, R., 2020. The missing focus on women's health in the First 1,000 Days approach to nutrition. Public Health Nutrition.

Kusumawati, E., Rahardjo, S., Sari, H.P., 2015. Model for controlling risk factors for stunting in children under three years. National Public Health Journal 9, 249.

MCA-Indonesia, 2013. Stunting dan Masa depan Indonesia. Jakarta.

Ministry of Health Indonesia, 2010. Decree of the Minister of Health of the Republic of Indonesia Number 1995 / Menkes / SK / XII / 2010 concerning Anthropometric Standards for Assessing the Nutritional Status of Children, Ministry of Health Indonesia. Indonesia.

Ministry of Health Indonesia, 2018. The Situation of Stunting in Indonesia. Health Data and Information Bulletin 1, 6-18.

Nadiyah, Briawan, D., Martianto, D., 2014. Faktor Risiko Stunting Pada Anak Usia 0-23 Bulan Di Provinsi Bali, Jawa Barat, Dan Nusa Tenggara Timur. Jurnal Gizi dan Pangan 9, 125-132.

National Development Planning Agency, 2011. National Action Plan for Food and Nutrition 2011-2015.

Niga, D.M., Purnomo, W., 2016. Hubungan Antara Praktik Pemberian Makan, Perawatan Kesehatan, Dan Kebersihan Anak Dengan Kejadian Stunting Pada Anak Usia 1-2 Tahun Di Wilayah Kerja Puskesmas Oebobo Kota Kupang. Wijaya 3, 151-155.
Nugroho, A., 2016. Determinan Growth Failure (Stunting) pada Anak Umur 1 S/D 3 Tahun (Studi di Kecamatan Tanjungkarang Barat Kota Bandar Lampung). Jurnal Kesehatan 7, 470.

Par'i, H.M., Wiyono, S., Harjatmo, T.P., 2017. Penilaian Status Gizi, Kementerian Kesehatan Republik Indonesia. Jakarta.

Pelletier, D.L., Frongillo, E.A., 2003. Changes in Child Survival Are Strongly Associated with Changes in Malnutrition in Developing Countries. The Journal of Nutrition 133, 107-119.

Pickering, A.J., Ercumen, A., Arnold, B.F., Kwong, L.H., Parvez, S.M., Alam, M., Sen, D., Islam, S., Kullmann, C., Chase, C., Ahmed, R., Unicomb, L., Colford, J.M., Luby, S.P., 2018. Fecal Indicator Bacteria along Multiple Environmental Transmission Pathways (Water, Hands, Food, Soil, Flies) and Subsequent Child Diarrhea in Rural Bangladesh. Environmental Science \& Technology 52, 7928-7936.

Rahman, F.D., 2018a. Pengaruh Pola Pemberian Makanan Terhadap Kejadian Stunting Pada Balita (Studi di Wilayah Kerja Puskesmas Sumberjambe, Kasiyan, dan Puskesmas Sumberbaru Kabupaten Jember). The Indonesian Journal of Health Science 10, 15-24.

Rahman, F.D., 2018b. The Effect of Feeding Patterns on the Incidence of Stunting in Toddlers. The Indonesian Journal of Health Science 10, 15-24.

Siringoringo, E.T., Syauqy, A., Panunggal, B., Purwanti, R., Widyastuti, N., 2020. Karakteristik Keluarga Dan Tingkat Kecukupan Asupan Zat Gizi Sebagai Faktor Risiko Kejadian Stunting Pada Baduta. Journal of Nutrition College 9, 5462.

Umboh, E., Wilar, R., Mantik, M.F.J., 2013. Pengetahuan Ibu Mengenai Manfaat Asi Pada Bayi. Jurnal e-Biomedik 1.

UNICEF Indonesia, 2018. Laporan Tahunan 2018 [WWW Document]. UNICEF Indonesia. URL https://www.unicef.org/indonesia/id/laporan/un icef-indonesia-laporan-tahunan-2018 (accessed 4.15.21).

Victora, C.G., Adair, L., Fall, C., Hallal, P.C., Martorell, R., Richter, L., Sachdev, H.S., 2008. Maternal and child undernutrition: consequences for adult health and human capital. The Lancet 371, 340357.

WHO, 2014. Stunting Policy Brief [WWW

Document]. URL https://www.who.int/nutrition/topics/globaltarg ets_stunting_policybrief.pdf 
WHO, 2017. Guideline: Updates on the management of severe acute malnutrition, WHO.

WHO, 2020. Stunting global and regional trends jme-(unicef-who-wb). WHO.

Widyaningsih, N.N., Kusnandar, K., Anantanyu, S., 2018. Keragaman pangan, pola asuh makan dan kejadian stunting pada balita usia 24-59 bulan. Jurnal Gizi Indonesia (The Indonesian Journal of Nutrition) 7, 22-29.
Yudianti, Y., Saeni, R.H., 2017. Pola Asuh Dengan Kejadian Stunting Pada Balita di Kabupaten Polewali Mandar. Jurnal Kesehatan Manarang 2, 21. 